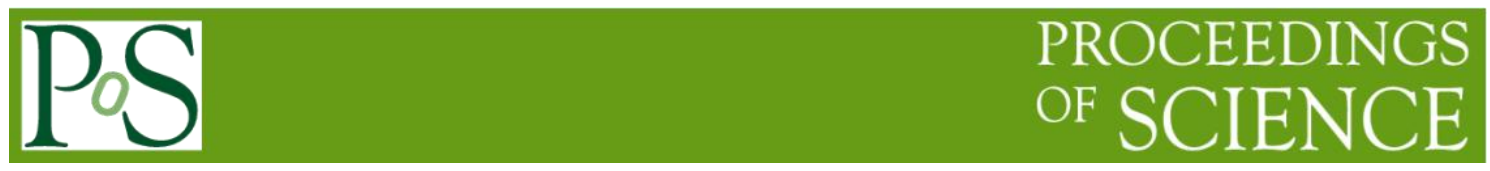

\title{
The five-year history of the Austrian Citizen Science Conference
}

\author{
Florian Heigl \\ Institute of Zoology, University of Natural Resources and Life Sciences Vienna \\ Gregor Mendel Strasse 33, 1180 Vienna, Austria \\ E-mail: florian.heigl@boku.ac.at

\section{Daniel Dörler} \\ Institute of Zoology, University of Natural Resources and Life Sciences Vienna \\ Gregor Mendel Strasse 33, 1180 Vienna, Austria \\ E-mail:daniel.doerler@boku.ac.at
}

5th Austrian Citizen Science Conference 2019 (ACSC2019)

26-28, June, 2019

Obergurgl, Austria 
In 2019 the Austrian Citizen Science Conference (ACSC) celebrated its 5th anniversary. We would like to take this anniversary as an opportunity to reflect on the development of the conference over the past 5 years. Since the beginning, the ACSC has been an annual milestone in the development of the Citizen Science Network Austria (CSNA) and its associated online platform Österreich forscht, www.citizen-science.at (Dörler and Heigl, 2019). Österreich forscht was launched in 2014 by a collective of students under the supervision of Johann Zaller at the University of Natural Resources and Life Sciences Vienna, Austria. Part of this student's collective were Daniel Dörler and Florian Heigl, the authors of this article, which are today also the coordinators of Österreich forscht, the CSNA and co-organizers of all ACSCs so far. The objectives of Österreich forscht (since 2014) and of the CSNA (since 2017) are to (I) connect all citizen science (CS) stakeholders in Austria, (II) further develop the method of CS, (III) quality management on the platform and (IV) foster CS as scientific method in the scientific as well as the non-scientific community.

\section{“Österreich forscht"}

In February 2015, the first ACSC "Österreich forscht" (Austria does research) was organized by the University of Natural Resources and Life Sciences in Vienna to connect CS stakeholders and interested persons not only online, but also on a personal level. Invited keynote speakers presented project examples in the field of ecology, archaeology, humanities, arts, economy and science communication. Experiences in using CS in higher education were presented as well as initiatives to foster CS in Europe. During a World café, a strategy for CS in Austria was discussed and a poster session gave existing CS projects the possibility to present themselves.

With the first conference, also the platform Österreich forscht was relaunched. The interest in the platform itself and the activities connected with it increased tremendously. In the following year, the number of projects presented on the platform increased from 9 to 29 and numerous press articles about CS in Austria followed. The conference showed the diversity of and the interest in CS in Austria, which finally resulted in the first funding for the platform activities, which previously were organised on a voluntary basis.

\section{“Citizen Science: Quo vadis?"}

The organisational structure of the conference changed significantly in February 2016 in Lunz am See. To reflect the collaborative nature of CS it was decided that the conference should not be organised only by the coordinators of the network alone every year, but rather together with a local partner, which means that the conference could now be held basically anywhere in Austria where someone agrees to host the conference. The local organisational team can also have a decisive influence on the focus of the conference. With this new way of organisation, the interest in the conference especially by local NGOs and local scientists increased. The decentralised organisation has also benefits for the network, for example local organisers bring in their expertise, and the diversity of partners in the network increases with the interest of local institutions (NGOs, museums, private research institutions, etc.). The first local organiser in 2016, the "WasserCluster Lunz am See", chose the motto "Citizen Science: Quo vadis?" with the aim to demonstrate to what extent this method can generate scientifically robust results. The conference featured international keynote speakers, oral 
presentations and a poster session. Workshops and a mini bar camp addressed urging questions regarding data quality, developments and challenges for CS in Austria and beyond (Heigl et al., 2016).

\section{"Expanding Horizons"}

In March 2017 together with the local organizer "AGES - Agentur für Gesundheit und Ernährungssicherheit" we decided to open up the conference. We organised a two-step call for contributions (first, call for session proposals, second, call for oral and poster presentations in these sessions as well as workshops). Furthermore, we included a public day in our conference in the Natural History Museum Vienna to give interested citizens the chance to experience Austrian CS projects in a hands-on manner. We chose a museum as location for the public day, since we made the experience with previous events, that the audience is bigger and more diverse, when the location is perceived as open for everybody like a park or museum.

This opening of the conference led to seven sessions with oral presentations and ten workshops from various scientific disciplines and the first time also including social sciences and humanities. During the public day project leaders presented their projects in 15 booths, and around 1700 visitors visited the museum that day, informing themselves about CS and ways to collaborate in projects in Austria (Dörler et al., 2018).

\section{"Generation Citizen Science"}

The successful way of organisation was continued in 2018, when the ACSC was organised by the University of Salzburg with oral and poster presentations as well as workshops, again from various scientific disciplines. The most significant innovation this year was the public day, which was carried out in several diverse locations all over the city of Salzburg. The public day included science cafés in actual cafés, a lab in a public bus, a "scientific kitchen" (to experiment with cooking recipes from the 18th and 19th century) and a big market arena with CS booths (Heigl, Dörler and Ernst, 2018). The ACSC 2018, was also a milestone in the history of Österreich forscht, because the quality criteria for CS projects on Österreich forscht were presented and have become effective then (Heigl, Dörler, Bartar, et al., 2018). With this process, Österreich forscht was the first CS platform, which installed such rigorous and transparent criteria for listed projects (Heigl et al., 2019).

\section{"Citizen Science: Borders and Transitions"}

2019 marked a special year. In collaboration with the University of Innsbruck the conference was organised at $2000 \mathrm{~m}$ above sea level in Obergurgl/Tyrol. The conference committee decided to have a one-step call for proposals with predefined session topics. The four topics namely (1) defining borders, (2) pushing the boundaries, (3) transitions: creating and transferring knowledge and (4) an open session framed the conference in a way that the participants deeply focused on what CS can achieve, where the limits of CS are and how these limits can be overcome.

This time the public day was designed especially for schools, and more than 200 students visited the market booths surrounded by mountains.

The conference 2019 was unique due to two reasons: first, it marked the day from which on all projects listed on Österreich forscht have fulfilled the quality criteria for CS 
projects and second, since January 2019, the CSNA and its associated platform have been permanently funded by the University of Natural Resources and Life Sciences Vienna.

\section{Conclusion and future direction}

As can be seen above, there have been many innovations and outstanding achievements in the 5 years of the conference's existence. From the very beginning, the ACSC was the central meeting point for the CS community in Austria and by collaborating with local organisers, we were able to maintain this position during the 5 years. The involvement of all stakeholders is a natural part of all CS activities; therefore, it was a special concern of ours to make the conference increasingly open over the years. In the coming years we would like to focus on organising the conference in such a way that all those involved in CS projects feel even more equally comfortable and welcome. Scientists with a focus on data analysis should find their opportunity for exchange as well as citizens only participate in a project from time to time but would like to exchange with the community. In summary, the exchange of ideas at eye level in a professional, respectful and comfortable atmosphere should be possible among all CS stakeholders at the conference.

\section{References}

Dörler D and Heigl F (2019) Citizen Science in Austria. Mitteilungen der Vereinigung Österreichischer Bibliothekarinnen und Bibliothekare 72(2). DOI: 10.31263/voebm.v72i2.2836.

Dörler D, Heigl F and Taru S (2018) Frontiers | Austrian Citizen Science Conference 2017 - Expanding Horizons. Frontiers Media SA. Available at: https://www.frontiersin.org/books/Austrian_Citizen_Science_Conference_2017__Expanding_Horizons/1444 (accessed 9 March 2018).

Heigl F, Dörler D, Weigelhofer G, et al. (eds) (2016) Austrian Citizen Science Conference 2016: Citizen Science - Quo Vadis? Lausanne: Frontiers Media SA. Available at: http://www.frontiersin.org/books/Austrian_Citizen_Science_Conference_2016/1026.

Heigl F, Dörler D and Ernst M (eds) (2018) Austrian Citizen Science Conference 2018. Lausanne: FrontiersIn. Available at: https://www.frontiersin.org/books/Austrian_Citizen_Science_Conference_2018/1719 (accessed 6 November 2018).

Heigl F, Dörler D, Bartar P, et al. (2018) Quality Criteria for Citizen Science Projects on Österreich forscht | Version 1.1. Open Science Framework. DOI: 10.17605/OSF.IO/48J27.

Heigl F, Kieslinger B, Paul KT, et al. (2019) Opinion: Toward an international definition of citizen science. Proceedings of the National Academy of Sciences 116(17): 8089-8092. DOI: 10.1073/pnas.1903393116. 